\title{
Implementasi Penggunaan Komputer Sebagai Media Dalam Meningkatkan Akreditasi Dan Mutu Pendidikan Di Smp Amir Islam Panyula Kabupaten Bone
}

\author{
Kasmawati \\ Universitas Muhammadiyah Bone \\ Email: awatikasma@gmail.com
}

\begin{abstract}
Abstrack. This study aims to determine the implementation of planning systems can improve the quality of education in SMP Amir Islam Panyula, Bone Regency. The type of research used in this research is qualitative with a descriptive approach. The subjects of this study were the principal, vice principal and teachers of SMP Amir Islam Panyula, Bone Regency, totaling 4 people with a distribution of 1 principal, 1 deputy principal and 1 teacher. The research instrument used in the form of observation and interviews. The data obtained were then analyzed by presenting the data for conclusion drawing and verification (conclusion drawing). Based on the results of the study indicate that the principal's efforts in improving the quality of education in SMP Darussalam are seen in the input, process, and output indicators. The principal's efforts to improve the quality of education related to input indicators are to prepare professional educators; either through coaching; discussions and meetings; academic seminars; include training, workshops; and education and training, perfecting student recruitment strategies through promotions. The efforts of the head of SMP Amir Islam Panyula, Bone Regency in improving the quality of education in relation to process indicators are planning for accreditation with a computer media system, creating a safe learning environment; cozy; and stimulate in learning, make programs according to the needs of students extracurricular activities, provide motivation to learn; both giving rewards and punishments to teachers and students. The efforts of the head of SMP Amir Islam Panyula, Bone Regency, in improving the quality of education in relation to output indicators, are trying to excel in academic and non-academic.
\end{abstract}

Key Word: Media, Accreditation, Quality Of Education

\section{PENDAHULUAN}

Dalam rangka meningkatkan mutu pendidikan nasional secara bertahap, terencana dan terukur sesuai amanat Undang-undang Nomor 20 Tahun 2003 tentang Sistem Pendidikan Nasional, BAB XVI Bagian Kedua Pasal 60 tentang Akreditasi, Pemerintah melakukan akreditasi untuk menilai kelayakan program dan/atau satuan pendidikan. Berkaitan dengan hal tersebut, Pemerintah telah menetapkan Badan Akreditasi Nasional Sekolah/Madrasah (BAN-S/M) dengan Peraturan Mendiknas Nomor 29 Tahun 2005. BAN-S/M adalah badan evaluasi mandiri yang menetapkan kelayakan program dan/atau satuan pendidikan jenjang pendidikan dasar dan menengah jalur formal dengan mengacu pada standar nasional pendidikan. Sebagai institusi yang bersifat mandiri dan bertanggung jawab kepada Mendiknas, BAN-S/M bertugas merumuskan kebijakan operasional, melakukan sosialisasi kebijakan dan melaksanakan akreditasi sekolah/madrasah. Dalam melaksanakan akreditasi sekolah/ madrasah, BAN-S/M dibantu oleh Badan Akreditasi Provinsi Sekolah/Madrasah (BAP-S/M) yang dibentuk oleh Gubernur, sesuai Peraturan Pemerintah Nomor 19 Tahun 2005 tentang Standar Nasional Pendidikan, khususnya Pasal 87 ayat (2).

Undang-undang Nomor 20 tahun 2003 tentang Sistem Pendidikan Nasional pasal 60 ayat 1 dan 2 menegaskan bahwa akreditasi dilakukan untuk menentukan kelayakan program dan satuan pendidikan pada jalur formal dan nonformal pada setiap jenjang dan jenis pendidikan, serta akreditasi terhadap program dan satuan pendidikan dilakukan oleh pemerintah dan /atau lembaga mandiri yang berwenang sebagai bentuk akuntabilitas publik.

Penyelenggaraan akreditasi, sebagai salah satu kegiatan peningkatan mutu dibidang pendidikan, pada hakekatnya adalah suatu upaya agar penyelenggara pendidikan dapat 
mencapai standar kualitas yang ditetapkan dan pada gilirannya peserta didik dapat mencapai keberhasilan pendidikan, baik dalam penguasaan ilmu pengetahuan, keterampilan maupun pembentukan kepribadian.

\section{Mutu Pendidikan}

\section{a. Pengertian Mutu Pendidikan}

Definisi mutu memiliki konotasi yang bermacam-macam tergantung orang yang memaknainya dan dari sudut pandang mana konsep tersebut dipersepsikan. Bersumber dari Kamus Besar Bahasa Indonesia mutu ialah ukuran baik atau buruk, keadaan, taraf atau derajat (kepandaian, kecerdasan dan sebagainya) (Depdiknas, 2009:677).

\section{b. Indikator Mutu Pendidikan}

Menurut Cepi Triatna (2015), mutu layanan pendidikan dapat dikategorikan berdasarkan pandangan sistem, yaitu kategori hasil, proses, masukan.

1) Mutu hasil ialah kebermutuan hasil pendidikan yang dirasakan utamanya oleh peserta didik sebagai wujud nyata dari proses pembelajaran.

2) Mutu proses adalah kebermutuan yang dilihat dari sejauh mana peserta didik merasa nyaman dengan layanan pembelajaran yang dilakukan oleh guru dengan berbagai sumber daya yang dimiliki sekolah.

1) Memiliki kepala sekolah yang profesional. Keprofesionalan kepala sekolah meliputi:

a. Rincian kualifikasi dan pengalaman kepala sekolah dalam memimpin sekolah.

b. Kepala sekolah menyediakan waktu untuk berbicara atau berdiskusi dengan orang tua maupun wali dari peserta didik.

c. Kepala sekolah menjunjung tinggi moral warga termasuk moral staf guru.

d. Kepala sekolah mampu melakukan kegiatan supervisi, khususnya kepada guru yang mengarah pada peningkatan pembelajaran.

\section{c. Faktor Pendukung dalam Meningkatkan Mutu Pendidikan}

Mutu pendidikan merupakan sesuatu yang diperjuangkan, maka dalam suatu usaha untuk mencapai tujuan yang diperjuangkan tersebut tidak lepas dari adanya beberapa faktor pendukung. Menurut Minnah El Widdah, terdapat sembilan faktor pendukung dalam meningkatkan mutu pendidikan di madrasah sebagai berikut:

1) Kurikulum dan Pembelajaran

Aspek kurikulum dan pembelajaran ini memiliki peranan yang sangat penting dalam keberhasilan program peningkatan mutu madrasah. Hal ini tidak hanya berupa dokumen tertulis yang memuat sejumlah mata pelajaran yang diajarkan pada siswa, tetapi juga memuat rumusan tujuantujuan yang hendak dicapai dalam rangka mewujudkan visi dan misi madrasah.

2) Sarana dan Prasarana

3) Ketenagaan (Guru dan Staf)

Seorang pendidik dituntut untuk menjadi guru yang profesional, maka harus mampu melakukan tugas-tugas keguruan terutama dalam merencanakan, melaksanakan dan menilai keberhasilan pembelajaran.

4) Siswa

Siswa termasuk salah satu kompenen inoput pada sistem sekolah, maka keadaan siswa harus dipertimbangkan sedemikian rupa sehingga dapat diproses untuk meningkatkan kompetensinya.

\section{d. Faktor Penghambat dalam} Meningkatkan Mutu Pendidikan

Praktik dalam usaha untuk meningkatkan mutu pendidikan tidak selamanya berjalan mulus dan lancar, terkadang muncul berbagai kendala dalam mewujudkan mutu pendidikan sebagaimana yang diharapkan. Adapun faktor-faktor penghambat meningkatkan 
mutu menjadi kendala sehingga mengalami kesulitan dalam meningkatkan mutu pendidikan, antara lain:

1) Lembaga pendidikan berbeda dengan layanan jasa dan perdagangan

Perlu dipahami bahwa tugas dari pendidikan agar siswa memiliki berbagai nilai dan kepercayaan yang semuanya sukar untuk diukur. Dalam layanan jasa dan perdagangan mudah untuk dihitung berapa modal, berapa barang terjual dan berapa keuntungan yang diperoleh. Akan tetapi, bukan sama sekali dalam pendidikan tidak dapat diukur seperti prestasi dan kecerdasan kognitif.

2) Tujuan pendidikan termasuk sukar diukur tingkat ketercapaiannya

Tercapainya tujuan pendidikan seharusnya tidak cukup pada nilai namun termasuk selesai dari proses belajar mengajar di sekolah. Tujuan pendidikan bersifat jangka panjang yaitu menyiapkan manusia yang baik. Manusia yang baik kadang kala tidak langsung dirasakan sebagai bukti tercapainya tujuan pendidikan tersebut, melainkan setelah mengalami proses panjang dalam rentang kehidupan manusia.

3) Hak pelanggan untuk menentukan pilihan pendidikan

Peserta didik di satu pihak sebagai pelanggan yang harus deberikan pelayanan pendidikan dan pembelajaran terbaik, namun di sisi lainnya sebagai manusia dapat menentukan sendiri pilihan terbaiknya. Pembentukan manusia tidak sama dengan pembentukan barang yang mudah direkayasa menjadi bentukbentuk baru.

4) Manajemen sekolah menghadapi masalah fragmentatif

Ketika dalam pengambilan keputusan sekolah banyak dipengaruhi oleh faktor tuntutan dari pihak luar, seperti wali siswa, pemerintah dan lapangan kerja. Unsur-unsur tersebut berada di luar dan sangat beragam kepentingan, tidak dalam jajaran manajemen sekolah, sehingga tarik menarik kepentingan sukar dihindarkan.

5) Kepala sekolah memiliki tugas mengajar yang berlebihan

Kepala sekolah terkadanterlalu sibuk dalam kegiatan mengajar, sehinggga kurang memiliki waktu untuk melaksanakan manajemen mutu pendidikan. Tugas rangkap sering kali menyebabkan tidak optimalnya tugas tersebut, karena tugas satu dengan lainnya tidak dapat dibatasi. Menjadi guru harus profesional, demikian juga menjadi kepala seoekolah sudah semsetinya harus profesional. Namun, profesional dalam dua bidang secara bersamaan seringkali menjadi kendala

6) Kepala sekolah dan guru memiliki profesi yang sama dengan guru

Dalam sistem koordinasi antara kepala sekolah dan guru terkadang menjadi saling bergesekan, sehingga berpengaruh terhadap tujuan bersama untuk mencapai mutu pendidikan (Wahjosumidjo, 2017).

7) Pengelola kurangnya wawasan untuk memperbaiki sistem kualitas

8) Penyelenggaraan pendidikan nasional yang sentralistik

Partisipasi masyarakat selama ini sangat minim, khususnya orang tua siswa dalam penyelenggaraan pendidikan pada umumnya lebih banyak bersifat dukungan dana, bukan turut andil dalam pengambilan keputusan, monitoring dan evaluasi (Surya, 2016).

e. Upaya Kepala Sekolah Meningkatkan Mutu Pendidikan

Berdasarkan indikator mutu pendidikan yang meliputi input, proses dan output, maka upaya kepala sekolah untuk meningkatkan mutu pendidikan melalui beberapa cara berikut:

1) Merumuskan visi, misi dan tujuan lembaga secara jelas serta berusaha keras mewujudkannya melalui kegiatan-kegiatan riil sehari-hari. 
2) Mengondisikan lingkungan pembelajaran yang aman, nyaman dan

\section{Akreditasi} menstimulasi belajar (Priansa, 2015).

\section{a. Pengertian Akreditasi}

Akreditasi sekolah adalah kegiatan penilaian yang dilakukan oleh pemerintah atau lembaga mandiri yang berwenang. Untuk menentukan kelayakan program atau satuan pendidikan formal dan non-formal pada setiap jenjang dan jenis pendidikan, berdasarkan kriteria yang telah ditetapkan, (Dahar, 2015). Pasal 60 ayat 1,2,3,4 lebih diperjelas bahwa akreditasi dilakukan untuk menentukan kelayakan program dan satuan pendidikan yang berada pada setiap jenjang, jenis dan jalur pendidikan (formal dan non formal), sedangkan untuk program dan satuan pendidikan dilakukan oleh pemerintah atau lembaga mandiri sehingga memiliki akuntabilitas publik yang tinggi. Selanjutnya proses akreditasi dilaksanakan dengan mendasarkan pada asas ketentuan.

\section{b. Tujuan Akreditasi}

Akreditasi ini dilakukan dengan tujuan untuk memperoleh gambaran keadaan kinerja sekolah dalam menyelenggarakan pendidikan, sebagai dasar yang dapat digunakan sebagai alat pembinaan dan pengembangan dalam rangka peningkatan mutu pendidikan di sekolah, (Depag RI, Direktoral Jendral Kelembagaan Agama Islam).

c. Manfaat Akreditasi

1) Dapat dijadikan sebagai acuan dalam upaya peningkatan mutu sekolah/madrasah dan rencana pengembangan sekolah/madrasah.

2) Dapat dijadikan umpan balik dalam usaha pemberdayaan dan pengembangan kinerja warga sekolah/madrasah dalam rangka menetapkan visi, misi, tujuan, strategi dan program sekolah/madrasah.

\section{d. Prinsip-Prinsip Akreditasi}

1) Objektif
2) Komprehensif

3) Adil

4) Akuntabel

e. Ruang Lingkup Akreditasi

Sekolah yang terakreditasi menurut (Eka Prihatin, 2011) meliputi:

1) Taman kanak-kanak (TK)/Raudhatul atfal (RA).

2) Sekolah Dasar (SD)/Madrasah Ibtidaiyah (MI).

3) Sekoah Menengah Pertama (SMP)/Madrasah Tsanawiyah (MTs).

\section{KERANGKA PIKIR}

Pendidikan yang baik dan bermutu menjadi dasar pengembangan dan kemajuan generasi bangsa sebagai pemegang tongkat estafet. Apabila zaman dahulu para pejuang memerangi penjajah, amanat yang diemban generasi masa ini ialah memerangi kebodohan. Untuk lebih jelasnya mengenai kerangka pikir dapat di lihat dalam skema sebagai berikut:

Skema Kerangka Pikir

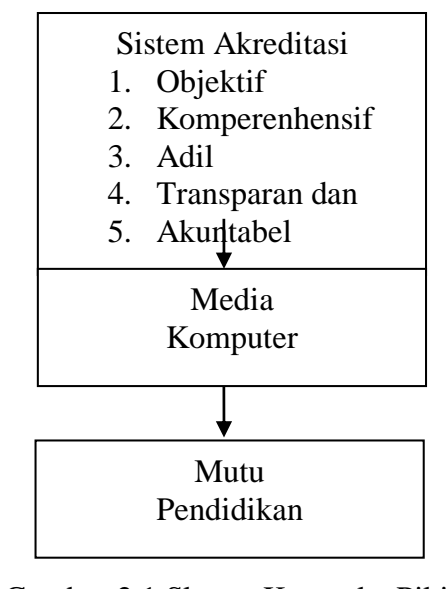

Gambar 2.1 Skema Kerangka Pikir

\section{METODE PENELITIAN}

\section{a. Jenis Penelitian}

Jenis penelitian kualitatif dengan kata lain penelitian yang menghasilkan data dalam bentuk deskriptif dari subjek dan informan pada suatu tempat penelitian yang telah ditentukan, adapun untuk penyelesaian yang diperoleh selama penelitian berupa kata-kata atau ungkapan tanpa adanya perhitungan data statistik. Penelitian ini bertujuan untuk mendeskripsikan 
Jurnal Ilmiah Mandala Education

http://ejournal.mandalanursa.org/index.php/JIME/index

Terakreditasi Peringkat 4 (No. SK: 36/E/KPT/2019)
Vol. 7. No. 3 Agustus 2021

p-ISSN: 2442-9511 e-ISSN: 2656-5862
"Implementasi Perencanaan dapat

Meningkatkan Mutu Pendidikan Di SMP

Amir Islam Panyula Kabupaten Bone".

b. Subjek dan Objek Penelitian

\section{Subjek penelitian}

Subjek penelitian adalah pihak-pihak yang hendak diteliti oleh peneliti, yakni pihak-pihak yang menjadi sasaran penelitian (Azwar, 2016:34). Adapun yang menjadi subjek dalam penelitian ini yaitu: Kepala Sekolah, Guru dan Wakil Kepala Sekolah.

Pada penelitian kualitatif, responden atau subjek penelitian ini disebut dengan istilah informan tentang data yang diinginkan peneliti berkaitan dengan penelitian yang sedang dilaksanakan.

\section{Objek penelitian}

Objek dalam penelitian ini adalh Informan atau pihak-pihak yang memberikan informasi yang diperlukan oleh peneliti (Abdul Majid, 2013:35). Informan dalam penelitian ini adalah Kepala Sekolah, Wakil Kepala Sekolah, dan guru di SMP Amir Islam Panyula Kabupaten Bone.

\section{c. Fokus Penelitian}

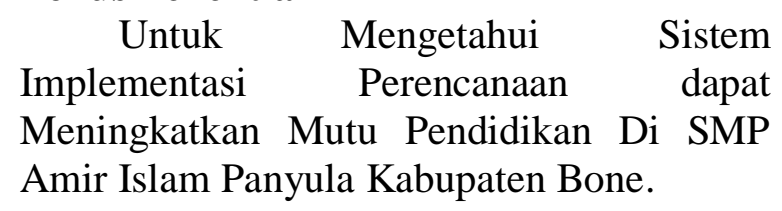

\section{d. Instrumen Penelitian}

1. Pedoman Observasi

Pedoman observasi ini merupakan alat yang memuat tentang apa-apa yang akandiobservasi dan hasil dari observasi itu.

2. Pedoman Wawancara

Pedoman wawancara adalah daftar pertanyaan yang digunakan sebagai acuan untuk menggali informasi dengan melakukan wawancara terkait pokok persoalan yang diteliti pada objek penelitian, dan dapat memberikan hasil yang diharapkan peneliti dalam proses penelitian, (J. Lexy Moleong, 2009).

3. Dokumentasi

Metode ini digunakan untuk memperoleh dokumen tentang kegiatankegiatan apa saja yang dilakukan
Implementasi Perencanaan untuk Meningkatkan Mutu Pendidikan Di SMP Amir Islam Panyula Kabupaten Bone.

\section{e. Teknik Pengumpulan Data}

Metode yang digunakan pada teknik pengumpulan data dalam penelitian ini adalah sebagai berikut:

1. Observasi

Observasi adalah mengoptimalkan kemampuan peneliti dari segi motif, kepercayaan, perhatian perilaku tak sadar, kebiasaan dan sebagainya dengan metode ini dapat diamati dan dicacat secara sistematis fenomena-fenomena yang diselidiki baik secara langsung maupun tidak langsung. (Moleong), dalam (Patta Bundu. 2016).

2. Wawancara

Wawancara adalah percakapan dengan maksud tertentu. Percakapan itu dilakukan oleh dua pihak, yaitu pewawancara (interviewer) yang mengajukan pertanyaan dan terwawancara (interviewe) yang memberikan jawaban atas pertanyaan itu, Moleong dalam (Patta Bundu. 2016).

3. Dokumentasi

Dokumentasi adalah setiap bahan tertulis maupun film dari recorder yang tidak dipersiapkan karena adanya permintaan seorang penyidik (Moleong) dalam (Patta Bundu. 2016).

Metode ini digunakan untuk memperoleh dokumen tentang kegiatankegiatan apa saja yang dilakukan Implementasi Perencanaan dalamt Meningkatkan Mutu Pendidikan Di SMP Amir Islam Panyula Kabupaten Bone”.

\section{HASIL PENELITIAN}

\section{a. Pembahasan}

Setelah data diketahui sebagaimana yang peneliti sajikan pada fakta temuan di atas, maka sebagai tindak lanjut dari penelitian ini ialah menganalisis data-data yang telah terkumpul. Adapun upaya kepala sekolah yang dilakukan dengan tujuan meningkatkan mutu pendidikan di SMP Amir Islam Panyula, sebagai berikut: 
Jurnal IImiah Mandala Education

http://ejournal.mandalanursa.org/index.php/JIME/index

Terakreditasi Peringkat 4 (No. SK: 36/E/KPT/2019)
Vol. 7. No. 3 Agustus 2021

p-ISSN: 2442-9511 e-ISSN: 2656-5862
Mutu pendidikan merupakan sesuatu yang harus diperjuangkan dengan memiliki indikotor input, proses, output. Kebermutuan suatu sekolah terlihat dari sejumlah ciri yang menyertai baik dari masukan (input), proses, maupun hasil (output). Seseuai dengan teori Triatna (2015: 53), karena sekolah sebagai lembaga pendidikan dapat dikatakan bermutu apabila memenuhi beberapa karakteristik diantaranya memiliki visi dan misi yang jelas, memiliki kepala sekolah yang profesional, memiliki guru yang professional, memiliki lingkungan sekolah yang kondusif untuk belajar, memiliki kurikulum yang luas dan berimbang, tinggi dalam melibatkan masyarakat untuk ikut serta mengelola sekolah (Triatna) dalam (Rusman, 2015). Adapun dalam segi proses, diarahkan kepada kinerja guru dalam mengajar serta kualitas pembelajaran yang disampaikan. Penyelenggaraan pendidikan tidak lepas dari peran utama kepala sekolah dan dibantu oleh tenaga pendidikan yang menyampaikan ilmu kepada para siswa. Untuk itu, kepala sekolah untuk menyiapkan tenaga pendidik yang lebih profesional maka memaksimalkan dalam penyediaan dan pembinaan tenaga pendidikan, (Triatna, 2015: 53).

Penyediaan tenaga pendidikan di SMP Amir Islam Panyula ditangani langsung oleh pihak yayasan dan komite serta kepala sekolah maka bisa dipastikan semua terlibat dalam rekruitmen, penyeleksian, penerimaan, penempatan dan penetepan.

Pembinaan untuk tenaga pendidikan di SMP Amir Islam Panyula dilaksanakan melalui beberapa program baik pembinaan dari pihak sekolah maupun pembinaan yang dilaksanakan di luar sekolah. Untuk pembinaan dari pihak sekolah sendiri berupa kegiatan supervisi, pembinaan rutin, rapat/briving setiap pagi, rapat, pengajian keluarga guru. Kegiatan supervisi sebagai wujud mutu input untuk meningkatkan mutu proses dan mutu hasil pembelajaran.
Pelaksanaan supervisi menerapkan teknik supervisi individual dan supervisi kelompok. Untuk supervisi individual di sini hanya berhadapan dengan seorang guru, diantaranya dengan kunjungan kelas, observasi kelas, pertemuan individual, kunjungan antar kelas dan menilai diri sendiri. Dalam melaksanakan supervisi ini kepala sekolah sebagai seorang supervisor, yang memili kendala pada masalah waktu. Sehingga untuk pelaksanaan kegiatan supervisi langsung waktu secara kondisional belum dapat terprogram secara rutin. Sedangkan untuk supervisi kelompok dilaksanakan oleh kepala sekolah sebagai supervisor yang kegiatan pengawasannya ditujukan kepada dua orang atau lebih, sehingga ini dapat berupa pengawasan kepala sekolah dalam mengamati kinerja guru misalnya ketika bekerja sama. Melalui kegiatan supervisi ini dapat meningkatkan profesionalitas guru dalam melaksanakan pembelajaran baik untuk mengplikasikan metode dan strategi yang melatih siswa untuk lebih aktif, selain itu guru dalam memanfaatkan media dan alat pendukung pembelajaran.

Pembinaan rutin dilaksanakan sekali dalam satu Minggu yaitu pada hari Sabtu setelah kegiatan pembelajaran jam terakhir, kegiatan ini diwajibkan untuk seluruh guru di SMP Amir Islam Panyula. Harapan utama dalam kegiatan pembinaan rutin ini, untuk membangun komunikasi antar guru juga dengan kepala sekolah dan yayasan supaya dapat terjalin sosialisasi yang baik. Adapun sasaran utama.

Upaya kepala sekolah dalam memaksimalkan pembinaan tenaga pendidikan termasuk melaksanakan briving setiap pagi. Dalam briving setiap pagi ini terdapat nilai pembiasaan dari kepala sekolah untuk membiasakan guru hadir tidak terlambat ketika pembelajaran pertama, maka dalam briving pagi tersebut di awali dengan do'a bersama, membahas sekilas kegiatan pembelajaran dan perkembangan siswa. Kepala sekolah memberikan teladan 
hadir lebih pagi, namun masih terdapat beberapa guru yang tidak mengikuti kegiatan briving karena kehadiraanya terlambat. Untuk rapat rutin yang dilaksanakan pada setiap 3 bulan maupun 6 bulan tersebut guna membahas dalam persiapan menjelang ujian tengah dan akhir semester. Selain itu, rapat pada akhir semester untuk membahas perencanaan maupun program untuk tahun pelajaran baru.

Salah satu usaha kepala sekolah dalam memaksimalkan perencanaan implementasi akreditasi menggunakan media komputer dalam peningkatan mutu pendidikan yaitu perencanaan akrediatsi sekolah yang maksimal sehingga dapat di jadikan sebagai acuan dalam upaya peningkatan mutu di SMP Amir Islam Panyula, dapat di jadikan sebagai motivasi agar sekolah SMP Amir Islam Panyula terus meningkatkan mutu pendidikan secara bertahap, terencana, dan kompetitif baik di tingkat kecamatan dan kabupaten/kota, membantu sekolah SMP Amir Islam Panyula dalam menentukan dan mempermudah ke pindah peserta didik dari satu sekolah ke sekolah yang lain, pertukaran guru dan kerja sama yang saling menguntungkan dan sebagai acuan bagi lembaga terkait dalam mempertimbangkan kewenangan sekolah sebagai penyelenggara ujian nasional.

Pihak sekolah harus mempersiapkan dalam melakukan akreditasi meperhatikan standar isi, standar proses, standar kompetensi lulusan standar pendidika dan kependidikan, standar sarana dan parsaran, standar pengelolaan, standar pembiayaan dan standar penilaian. Selanjutnya hal ini dapat menjadi motivasi diri untuk meningkatkan dan memberikan pelayanan sesuai dengan kriteria yang di tetepkan dalam akreditasi, dapat mengetahui kekurangan yang di miliki sekolah dan sebagai bahan perbaikan sekolah ke depan. tumbuhnya kesadaran untuk meningkatkan mutu pendidikan melalui pencapaian standar yang telah di tetapkan, bagi guru, lebih terdorong untuk selalu meningkatkan diri dan bekerja keras dalam memberikan layanan terbaik bagi peserta didik dan meningkatkan mutu pendidikan dan bagi siswa menumbuhkan rasa percaya diri bahwa mereka mendapatkan pendidikan terbaik dan harapanx sertifikat dari sekolah yang terakreditasi merupakan bukti bahwa mereka mendapatkan pendidikan bermutu.

\section{SIMPULAN}

Berdasarkan hasil penelitian dan pembahasan mengenai Implementasi Perencanaan Dalam Meningkatkan Mutu Pendidikan Di SMP Amir Islam Panyula Kabupaten Bone, bahwa mutu pendidikan dapat dilihat pada indikator mutu yaitu, input, proses, dan output. Berikut ini dapat disimpulkan, beberapa upaya yang dilakukan kepala sekolah dalam meningkatkan mutu pendidikan: Upaya kepala sekolah dalam meningkatkan mutu input pendidikan melalui, menyiapkan pendidik yang profesional sebagai salah satu cara untuk meningkatkan mutu pendidikan, karena apabila memiliki tenaga pendidik yang profesional akan melakukan proses pembelajaran secara efektif dan menghasilkan lulusan yang berprestasi. Mutu pendidikan akan tercapai dengan peran serta dari masyarakat, untuk itu kepala sekolah juga meningkatkan promosi untuk menyempurnakan strategi rekrutmen siswa, karena dilihat dari segi kuantitas input siswa masih rendah dan upaya kepala sekolah selanjutnya dalam meningkatkan mutu hasil dari SMP Amir Islam Panyula dengan memberikan kesempatan para siswa-siswi untuk diikutsertakan dalam kegiatan lomba baik antar siswa dilingkup sekolah, tingkat Kecamatan ataupun Kabupaten. Selain itu, kepala sekolah juga mengupayakan program-program terencana sebagai persiapan meningkatkan kualitas siswa menghadapi ujian Nasional dengan harapan meraih kelulusan $100 \%$. Dalam pelaksanaan atau implementasi sistem akreditasi 
menggunakan media komputer sangat membantu dalam persiapan akreditasi maupun tahapan persiapan menuju pelaksanaan akreditasi sekolah, setelah pelaksanaan sistem akreditasi menggunakan media komputer dapat memperoleh gambaran kinerja sekolah dan menentukan tingkat kelayakan pelaksanaan akreditasi sekolah.

\section{Saran}

Dari hasil hasil penelitian tersebut, maka peneliti berusaha memberikan beberapa saran yang mungkin dapat membantu dalam meningkatkan mutu pendidikan di SMP Amir Islam Panyula. Adapun beberapa saran tersebut adalah sebagai berikut:

1. Bagi kepala sekolah, hendaknya lebih menyempurnakan strategi mengenai peningkatan mutu pendidikan itu sendiri dan pelaksanaan rekrutmen siswa secara proaktif dengan sistem menjemput, agar dapat meningkatkan kuantitas dalam memperoleh input siswa.

2. Bagi guru, hendaknya turut berperan aktif dalam rekrutmen siswa untuk memperoleh input siswa yang lebih meningkat kuantitasnya.

3. Bagi siswa, hendaknya siswa lebih meningkatkan lagi prestasi akademik dan non akademik. Untuk itu, akan membangun citra lembaga pendidikan SMP Amir Islam dan tentunya bisa bersaing dengan sekolahsekolah lain.

\section{DAFTAR PUSTAKA}

Abdul Majid. 2013. Strategi Pembelajaran. PT. Remaja Rosdakarya, Bandung.

Agus Suprijono.2014. Cooperative Learning (Teori Dan Aplikasi PAIKEM). Pustaka Pelajar, Yogyakarta.

Aji Supriyanto. 2015. Pengantar Teknologi Informasi. Jakarta : Salemba

Azhar Arsyad. 2016. Media Pembelajaran. Jakarta: Raja Grafindo Persada.

Dahar. 2015. Konsep Manajemen Akreditasi . Bandung: Alfabeta.
Donni Juni Priansa. 2015. Manajemen Peserta Didik Dan Model Pembelajaran. Alfabeta, Bandung.

Kokom Komulasari. 2015. Pembelajaran Kontekstual Konsep dan Aplikasi. Bandung: PT. Refika Aditama.

Nana Syaodiah Sukmadinata. 2016. Landasan Psikologi Proses Pendidikan. Bandung: PT Remaja Rosdakarya.

Patta Bundu. 2016. Penilaian Keterampilan Proses dan Sikap Ilmiah dalam Pembelajaran Sains Sekolah Dasar. Jakarta: Departemen Pendidikan dan Kebudayaan Direktorat Jenderal Pendidikan Tinggi Proyek Pembinaan Tenaga Kependidikan.

Rusman. 2015. Model-model Pembelajaran. Jakarta: PT Raja Grafindo Persada.

Surya. 2016. Kapita Selekta Kependidikan Di $S D$, Jakarta, UT

Triatna. 2015. Manajemen Pendidikan. Bandung: Alfabeta.

Wahjosumidjo, 2017. Pembelajaran Konstektual dan Penerapannya dalam KBK. Malang : Universitas Negeri Malang. 